\title{
The Impact of Motivating Iranian EFL Learners via Visuals on Their Listening Comprehension
}

\author{
Masoumeh Karimi \\ Department of Foreign Languages, Khorasgan (Isfahan) Branch, Islamic Azad University, Isfahan, Iran \\ Reza Biria \\ Department of Foreign Languages, Khorasgan (Isfahan) Branch, Islamic Azad University, Isfahan, Iran
}

\begin{abstract}
Teaching listening has always been a big challenge for many foreign or second language teachers. One of the most important factors in this respect is the students' lack of interest in doing so. In order to solve this problem the use of visuals as a motivating factor for improving the students listening comprehension is suggested. A number of 150 elementary students were selected. They were divided into 2 language proficiency homogeneous groups. To compare the change in the degree of their motivation two sets of questionnaire were given to them. The control group was exposed to the listening material without seeing any visuals and just having a short oral pre listening activity, while the experimental group were shown a picture of the situation in which the conversation was taking place, while some predicting questions were raised. Then a listening comprehension test was given to both groups. By using statistical procedures a correlation was taken for comparing the motivation and listening comprehension scores and a t-test was measured for comparing the listening comprehension scores of the experimental group and the control groups. The results indicated that the use of visuals improves the listening comprehension of the subjects using visuals also improves their motivation.
\end{abstract}

Index Terms - motivation, listening comprehension visual aids

\section{INTRODUCTION}

As Anderson (1988) explains, it is sometimes observed that second language students' lack of listening comprehension is neither due to the voice quality nor language proficiency but it is because they do not want to do so. Some enormous researchers (Anderson, 1988, Ur, 1984, Brown, 2000) emphasized the importance of activating the learners' schematic information or background knowledge and benefit from their previous information in comprehending the material better; as Brown \& Yule (1983) mention, in any context of conversation we will not be able to comprehend people if we do not have a presupposition about what they are going to talk. Therefore, providing the students with a "presupposition pool" will help them improve their comprehension. And this will be done through a pre-listening activity which will not only activate the students' background knowledge, but will also play a motivating role in the students. However, as current studies demonstrate a short pre-listening activity of as short as five minutes will help the listener to construct a " mental model" (Anderson, 1988), and make predictions about what they are going to hear (Ur, 1984) and these all make them motivated and anxious to listen. The importance of motivation in language teaching has been emphasized by many educators (Anderson, 1988; Ur, 1984; Benson, 1989; Sheerin, 1987;Field,Brown, 1993;Mccellanel, 1940; Brown, 2000;Smit, 2002;Cormon,1986; Shelppegell, 1997; Noris, 2001). So the purpose of this study is to determine whether motivating the Iranian EFL learners via visuals has any impact on their listening comprehension.

\section{LITERATURE REVIEW}

\section{A. Motivation}

Motivation is a drive, impulse or desire that moves one to a particular action or helps people make different choices in their lives. (Brown, 1993; Beck, 1990; Petri, 1990). During the last 100 years the approach to motivation has changed a lot. Motivational research today may consider three major approaches: behavioral, cognitive, and humanistic. While behaviorists consider rewards as intrinsic motivating factor for the enforcement of a behavior (Thorndike, 1913), Hunt (1965) points out that we may often be motivated in a task not because of external rewards which are associated with it but because the behavior itself is rewarding. Hunt has in fact defined intrinsic motivation as the pleasure accompanied with a behavior regardless of the goal toward which it is directed. Spaulding (1992) believes that intrinsic motivation is evidenced whenever students natural curiosity and interest energize their learning.

Humanists are in this belief that individuals need to be successful, to improve and they want to reach the state of selfsatisfaction; this self satisfaction is also gained when the students try to receive the others as well as their own appreciation that's why some times students look for challenging tasks. Atkinson (1964) in his theory of achievement 
motivation clearly demonstrates this fact by stating that person's desire intermediate risk. Hence success (a reward) at an easy task does not increase the probability of undertaking that task again. Accordingly for a task to be motivating some amount of challenge is needed. In this respect Vygotsky (1978) mentions that there should be a balance between challenging and easy tasks. He believes that tasks which are beyond the person's Zone of proximal development are too difficult for the person to complete and tasks that are in the zone of the person's current development are easy enough that the person can successfully accomplish them without assistance of any sort. So for the students to maintain their intrinsic interest, academic assignment should be consisted of an appropriate balance between tasks in their zone of current development. When students are assigned tasks which are too difficult, beyond their zone of proximal development, they experience only failure, and their intrinsic motivation is necessarily undermined. In contrast tasks that are in their zone of current development but are a little challenging and they can fulfill it successfully increase their intrinsic motivation.

\section{B. Teaching Listening Comprehension and the Related Theories}

In recent years it seems as if the language teaching profession has placed a great emphasis on listening comprehension. According to Brown (2000) it is certainly because the language educators have noticed the importance of reception through which linguistic information is internalized over production. Though it seems as if speaking is the center of attention and it is a person's second language speaking which shows whether he or she knows the language or not, we should not forget that it is comprehension which precedes speaking. The idea of comprehending and listening before speaking was first introduced by Nida (1977b) when she proposed "passive (global) listening" and "selective listening" Global listening is actually a very active proves. Nida points out that the mind operates on incoming language input even when we are not making a conscious effort to learn; the mind assimilates, sorts and stores the many features of the input in order to gain total impression of its form and meaning. Asher's (1977) total physical response method is in accordance with Nida's theory. Later in other approaches such as natural approach, the priority was on listening in silence and students did not have to produce anything until they felt comfortable to do so. The research on the importance of input lead to Krashen's introduction of comprehensible input (1985) in which he explained the notion of $(+1)$ that is for the input to be converted into intake, the listening material should be just a little above the learner's present ability. Krashen points out that a good language classroom is designed to make input comprehensible through extra linguistic support (use of visuals, gestures, and context) and by use of textual features (repetition, redundancy, and simplification). In selective listening, attention is directed towards specific language features. Later on the idea of converting the input into intake became very crucial in considering the role of listening in language learning. The study of listening comprehension investigates the process of listening and the effect of a number of different contextual characteristics and how they affect the speed and efficiency of processing aural language. Morely (1994) emphasizes the importance of listening activities in the classes and mentions that teachers who want to provide the most effective classroom experience for their students should consider that language input is as easy to process as spoken language received through listening. At the beginning stages of language study, before students have learned to read well, it is by listening that they can have the most direct connection to the meaning of the new language.

At the intermediate level, when students are refining grammatical system listening can be used to promote accuracy. At advanced levels regular program of listening can extend the limits of learners' vocabulary. And use of idioms, and build their appreciation for cultural nuances.

Anderson (1988), to define the factors affecting a successful listening, mentions that there are different ways in which a listener can or cannot process what he or she has heard.

1. Listener may not hear adequately

2. Lack of language proficiency

3. The listener is not interested in what is being said: He or she hears and understands but may have switched off consciously or unconsciously.

4. Listener wants to know about what is being said: there are messages that the listener attends to fully and from which he tries to construct a coherent interpretation.

Sometimes to find out if listener comprehended something, we ask the listener to talk about his own interpretation of what he has heard, so in this model listener is active and constructs a mental model. In order to construct an adequate mental model of a message you need to resort to some sources:

- General factual knowledge

- Local factual knowledge

- Socio cultural knowledge

The listeners' knowledge of the context of situation and background knowledge of the culture and society are crucial to listening comprehension. Any sentence listeners hear is matched against their mental models of the world as reflected in scripts and schemas. If the model of speaker and listener differ too much, they will have problem understanding each other.

Anderson (1988) mentions that background problems are either because of gaps in our knowledge of L2 culture, associations and references available to native speakers or lack of enough background knowledge which leads to misunderstanding even among native speakers. 
There are different approaches to listening comprehension; information processing model can be considered one of these approaches in which the goal is the activation of students' background knowledge and the use of their schema in predicting what will come next. Teaching schemata use has been found to increase second language comprehension (Loyed \& Carrel, 1987; Hudson, 1982). However instruction in schemata use is not enough in itself. Unless students have a strategy for checking the accuracy of their assumptions, schemata use may actually interfere with comprehension. (Block, 1986; Kasper, 1984).The second approach we can refer to is making a distinction between product versus process which has become an important one for all language skills, particularly, those labeled "receptive" and it signals an increasing recognition that language is a fixed system, a finished product is just one part of the picture. In recent years it seems as if the language teaching profession has placed a great emphasis on listening comprehension. According to Brown (2000) it is certainly because the language educators have noticed the importance of reception through which linguistic information is internalized over production. Though it seems as if speaking is the center of attention and it is a person's second language speaking which shows whether he or she knows the language or not, we should not forget that it is comprehension which precedes speaking. The idea of comprehending and listening before speaking was first introduced by Nida (1977b) when she proposed "passive (global) listening" and "selective listening" Global listening is actually a very active proves. Nida points out that the mind operates on incoming language input even when we are not making a conscious effort to learn; the mind assimilates, sorts and stores the many features of the input in order to gain total impression of its form and meaning. Asher's (1977) total physical response method is in accordance with Nida's theory. Later in other approaches such as natural approach, the priority was on listening in silence and students did not have to produce an thing until they felt comfortable to do so. The research on the importance of input lead to Krashen's introduction of comprehensible input (1985) in which he explained the notion of $(+1)$ that is for the input to be converted into intake, the listening material should be just a little above the learner's present ability. Krashen points out that a good language classroom is designed to make input comprehensible through extra linguistic support (use of visuals, gestures, and context) and by use of textual features (repetition, redundancy, and simplification). In selective listening, attention is directed towards specific language features. Later on the idea of converting the input intointakebecame very crucial in considering the role of listening in language learning. The study of listening comprehension investigates the process of listening and the effect of a number of different contextual characteristics and how they affect the speed and efficiency of processing aural language. Morely (1994) emphasizes the importance of listening activities in the classes and mentions that teachers who want to provide the most effective classroom experience for their students should consider that language input is as easy to process as spoken language received through listening. At the beginning stages of language study, before students have learned to read well, it is by listening that they can have the most direct connection to the meaning of the new language.

Attention is paid to human beings as language processors than was previously the case. It is with the skills of listening that "processing" focus is most crucial. Sheerin (1987) explains that it is not just enough to examine the product that is whether the listener could understand or not. He emphasizes that we should pay a lot of attention to what may have gone wrong in the process of listening. If we do not do so, learners will use the same unsuccessful techniques on and on and they will not experience any improvement. From the process perspective wrong answers can be seen to be of more significance than correct ones. Teachers follow up incorrect responses in order to determine where understanding broke down.

Sheerin (1987) talks about teaching listening rather than testing it. She includes teaching effective listening involves adequate support and the provision of adequate task.

Morreale (2001) makes a distinction between competent and skillful listening. According to him a skillful listener understands the listening process, processes a set of listening skills, and is able to choose among and use those skills. While a Competent Listener includes the willingness to listen in a variety of different situations. Accordingly a Competent listener is the one who

- wants to listen effectively in a variety of situations

- Knows what to do to listen effectively in a variety of situations.

- Demonstrates the ability to listen effectively in a variety of situations.

So two elements transform skillful listening into competent listening. The motivation to listen effectively and the ability to do so across a variety of situations. People listen well when they are motivated to do so, for example when you like or admire the person who is speaking, or the person is communicating the information you want or need to know.

If you are a competent listener, you are motivated to listen even when you would rather not. So a competent model for listening calls for the listener to apply motivation, knowledge and skills to the three steps of receiving, constructing meaning and responding.

Morely (1994) and Brown (2000) introduce some principles for designing and performing listening techniques in the classroom

1. Increase the amount of listening time in second language classes

Input must be interesting, comprehensible, supported by extra linguistic materials and keyed to the language lesson. Teachers sometimes incorrectly assume that the input provided in the classroom will always be converted into intake. 
2. Use listening before other activities: have the students listen to the material before they acquire to speak, read or write about it.

3. Utilize authentic language and contexts.

4. Activate top- level skills: Use techniques that are intrinsically motivating

5. Let the students do some predicting

6. Encourage the development of listening strategies: looking for key words, nonverbal cues to meaning, guessing at meanings

In recent years it seems as if the language teaching profession has placed a great emphasis on listening comprehension. According to Brown (2000) it is certainly because the language educators have noticed the importance of reception through which linguistic information is internalized over production. Though it seems as if speaking is the center of attention and it is a person's second language speaking which shows whether he or she knows the language or not, we should not forget that it is comprehension which precedes speaking. The idea of comprehending and listening before speaking was first introduced by Nida (1977b) when she proposed "passive (global)listening " and "selective listening" Global listening is actually a very active proves. Nida points out that the mind operates on incoming language input even when we are not making a conscious effort to learn; the mind assimilates, sorts and stores the many features of the input in order to gain total impression of its form and meaning. Asher's (1977) total physical response method is in accordance with Nida's theory. Later in other approaches such as natural approach, the priority was on listening in silence and students did not have to produce an thing until they felt comfortable to do so. The research on the importance of input lead to Krashen's introduction of comprehensible input (1985) in which he explained the notion of $(+1)$ that is for the input to be converted into intake, the listening material should be just a little above the learner's present ability. Krashen points out that a good language classroom is designed to make input comprehensible through extra linguistic support (use of visuals, gestures, and context) and by use of textual features (repetition, redundancy, and simplification). In selective listening, attention is directed towards specific language features. Later on the idea of converting the input into intake became very crucial in considering the role of listening in language learning. The study of listening comprehension investigates the process of listening and the effect of a number of different contextual characteristics and how they affect the speed and efficiency of processing aural language. Morely (1994) emphasizes the importance of listening activities in the classes and mentions that teachers who want to provide the most effective classroom experience for their students should consider that language input is as easy to process as spoken language received through listening. At the beginning stages of language study, before students have learned to read well, it is by listening that they can have the most direct connection to the meaning of the new language listening for general gist.

The use of schemata promotes restructuring of language data so that greater segments of text can be grasped as a whole Carrell and Eisterhold (1983) point out that background information in the listener's mind is of two kinds: content schemata and formal schema. The former includes cultural knowledge, topic familiarity, and previous experience with a field. The latter refers to people's knowledge of discourse form: text types, rhetorical conventions, and the structural organization of prose. Both can help the listener in comprehending text.

\section{Motivating Factors in Teaching Listening Comprehension}

According to Galindo (1997) learners learn best when they can see a goal and can progress toward it. In real life when we listen to some one talking, we have a definition on-linguistic reason for doing so. In the classroom the genuine reason for listening is purely linguistic .So a nonlinguistic purpose has to be consciously superimposed in the form of a task.

According to Galindo (1997) learners learn best when they sense mastery. Sheerin (1987) mentions that listening exercises are meant to train not to test, and as Ur (1984) mentions the best practice is obtained by having learners do the activity more or less successfully not by having them fail. Sheerin again sites the old saying that: "nothing succeeds like success."

Learners also learn best when they see a relevance between the class topic and their lives.(Ur,1984) Listening to familiar text does not demand such intensive exercising of the perception or comprehension skills since the students know the content without being have to listen but it has the value of distinguishing between listening for perception or listening for comprehension.

Speaking and listening need to be reacted to immediately. And the learning value of listening exercises is increased if there is immediate teacher feedback on student performance. Sheerin (1987) believes that positive feedback for learners means ensuring that they experience success as often as possible.

Task based teaching is crucial in motivating students to listen. We use different visuals which have the function of aids to learning, simply because they attract students attention. It will be much more interesting to respond actively to something.(Ur 1984).Cook (1991) in favor of task based teaching of listening mentions that this approach helps the teacher to check that comprehension is taking place.

\section{Using Visuals and Other Environmental Clues}

Sherwyn (2001) mentions that visual aids assist in illustrating or supporting the content of a speech and add interest and excitement to it. They are useful when you need to clarify a difficult concept, present a complex idea, or demonstrate a process the audience would have difficulty understanding. Some environmental, usually visuals, 
accompaniment to heard discourse is a characteristic of most listening situations. In the classroom these environmental clues will usually be represented by different kinds of visuals: pictures, sketches on the board or over head projects. Ur (1984) emphasizes that the presence of such materials is of immense value in contextualizing and bringing to life the listening situation as well as in aiding comprehension of language .She strongly believes that some kind of visual clue is essential in any language learning activity based on face to face communication. Visuals have an important function as aids to learning, simply because they are motivating, attract students' attention and help and encourage them to focus on the subject in hand. Ur (1984) mentions that it is relatively difficult to concentrate on spoken material that is heard blind, far easier if there is something relevant to look at.

\section{METHOD}

\section{A. Subjects}

The subjects participating in this study were randomly selected among elementary students of English at The Iran Language Institute. Two groups were selected at random.

An independent t-test was run to compare the mean scores of the experimental and control groups on the proficiency test. The t-observed value, 1.13, at 115 degrees of freedom was lower than the critical value of t, i.e. 1.96. (Table1). It could be concluded that there was not any significant difference between the two groups mean scores on the proficiency test. As displayed in Table 2 the mean scores for the experimental and control groups score, 23.65, and 22.77 respectively (Table 2) It could be concluded that the two groups were homogenous in terms of their language proficiency.

The F-test was run to investigate the homogeneity of the variances of the two groups $(\mathrm{F}=2.15)$ had a probability of .14, indicating that the two groups were homogenous in terms of their variances (Table1).

TABLE 1.

INDEPENDENT T-TEST: PROFICIENCY TEST

Independent Samples Test

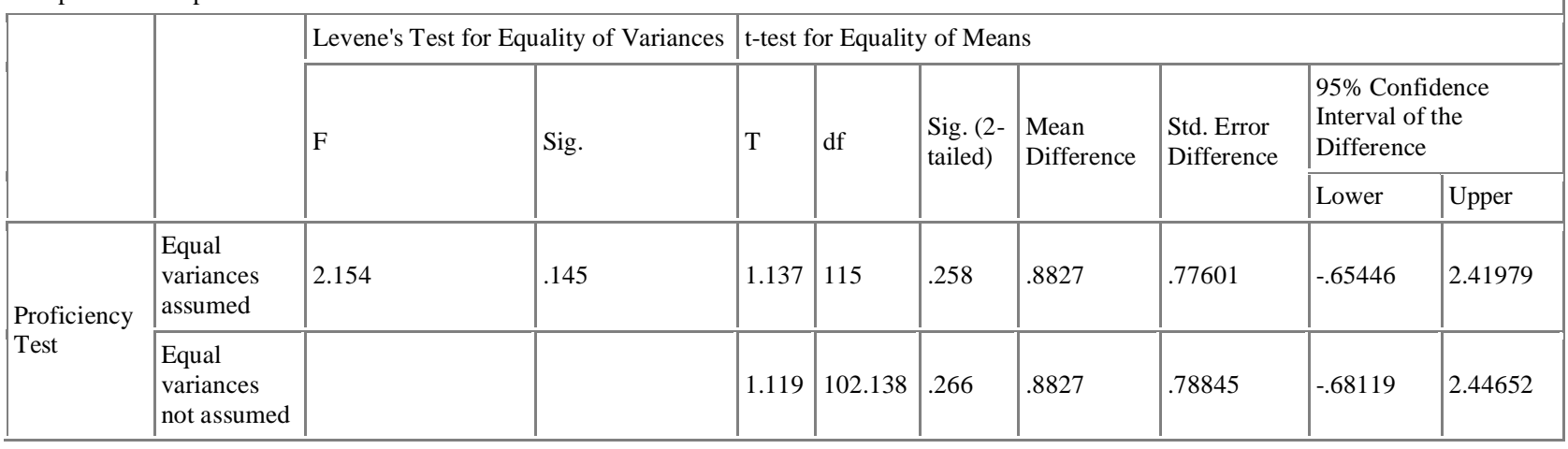

TABLE2.

DESCRIPTIVE Statistics: PROFICIENCY TEST

\begin{tabular}{|c|c|c|c|c|c|}
\hline & GROUP & $\mathrm{N}$ & Mean & Std. Deviation & Std. Error Mean \\
\hline \multirow{2}{*}{$\begin{array}{l}\text { Proficiency } \\
\text { Test }\end{array}$} & experimental & 64 & 23.6563 & 3.84303 & .48038 \\
\hline & Control & 53 & 22.7736 & 4.55159 & .62521 \\
\hline
\end{tabular}

\section{B. Instrumentation}

To conduct this study, there were data collection instruments:

First a thirty five -item multiple choice test was developed in order to see if the subjects are homogeneous regarding their language proficiency; The test consisted of questions taken from Nelson's language proficiency tests.

The Second instrumentation was a Persian translation of a modified version of the Attitude/ Motivation Test Battery (AMTB; Gardner, 1985) to measure the motivation of the learners. This Test Battery consisted of 36 items in a Likert type scale. Each item scored one to five, making a total from 36 to 180 for each complete questionnaire. This test battery included a variety of subscales and each was meant to measure one aspect of the attitudinal or motivational characteristics of the individuals under study. Dastgheib (1996) has cited a number of researchers who had reported a satisfactory level of reliability and validity of the measures used in this test battery. (e.g. Gilksman, 1976,1981; Lalonde and Gardner, 1984; Gardner, Lalonde and Moorcraft, 1985; Gardner and Lysynk, 1990; Gardner and Maslintyre, 1991).Gardner's adapted version of AMTB had been supplemented by items developed in a pilot study by Dastgheib who conducted the pilot study among learners in two different schools. 
In order to make the test appropriate for Iranian students, minor changes had been made in some of the items. The questionnaire had been translated into Persian and the accuracy of the translated copy had been checked by back translation method.

A pilot study conducted by Dastgheib indicated a satisfactory level of overall internal consistency reliability of .91.

Then a totally adapted version of a questionnaire written by Schimidt (1996) was given which aimed to measure the level of motivation generated during class by the materials in use. The questionnaire was also translated into Persian. To test the homogeneity of their listening comprehension a thirty item multiple choice test was developed by the researcher the material of which was taken from some authentic books such as New Interchange series.

And the last instrumentation was another teacher made listening test for the purpose of measuring their listening comprehension after the period of performing the treatment.

\section{Procedure}

The experimental group were treated by being shown some visuals related to the topic to which they were going to listen. Some predicting questions were raised as well in order to motivate the students toward finding the answer in the listening, while the control group had the predicting questions without seeing the pictures. To see if the use of visuals before listening would cause any significant difference.

\section{Data Collection}

The questionnaire and a test of proficiency were administered to the students.

The scores were entered into SPSS program. Because the first questionnaire, Gardner's, was in the form of popular 5point Likert type scale, the responses had to be weighted. As Ary, Jacobs and Razavieh (1996) state, for favorable or positively stated items the numerical values 5,4,3,2 and 1, respectively were assigned to the response categories beginning at the favorable end. For example" strongly agree" with a favorable statement received at weight of 5, "agree" 4, "strongly disagree" weight of 1 . For unfavorable or negative stated items the weighting was reversed, because disagreement with an unfavorable statement is psychologically equivalent to agreement with a favorable statement. Thus for unfavorable statements strongly agree received a weight of 1 and strongly disagree a weight of 5 . The sum of the weights of all the items would present the individual's total scores.

A pre test of listening was administered too, to make sure that the subjects were homogeneous in their listening skill. (Table 3)

TABLE 3

INDEPENDENT T-TEST: LISTENING PRETEST

Independent Samples Test

\begin{tabular}{|c|c|c|c|c|c|c|c|c|c|c|}
\hline & & \multicolumn{2}{|c|}{$\begin{array}{l}\text { Levene's Test for } \\
\text { Equality of Variances }\end{array}$} & \multicolumn{7}{|c|}{ t-test for Equality of Means } \\
\hline & & \multirow[t]{2}{*}{$\mathrm{F}$} & \multirow[t]{2}{*}{ Sig. } & \multirow[t]{2}{*}{$\mathrm{T}$} & \multirow[t]{2}{*}{ df } & \multirow{2}{*}{$\begin{array}{l}\text { Sig. (2- } \\
\text { tailed) }\end{array}$} & \multirow{2}{*}{$\begin{array}{l}\text { Mean } \\
\text { Difference }\end{array}$} & \multirow{2}{*}{$\begin{array}{l}\text { Std. Error } \\
\text { Difference }\end{array}$} & \multicolumn{2}{|c|}{$\begin{array}{l}95 \% \text { Confidence Interval of } \\
\text { the Difference }\end{array}$} \\
\hline & & & & & & & & & Lower & Upper \\
\hline \multirow{2}{*}{$\begin{array}{l}\text { Listening } \\
\text { Pretest }\end{array}$} & $\begin{array}{l}\text { Equal variances } \\
\text { assumed }\end{array}$ & .964 & .328 & -.106 & 115 & .916 & -.0696 & .65579 & -1.36857 & 1.22942 \\
\hline & $\begin{array}{l}\text { Equal variances } \\
\text { not assumed }\end{array}$ & & & -.107 & 112.987 & .915 & -.0696 & .65225 & -1.36181 & 1.22266 \\
\hline
\end{tabular}

The F-test was also run to investigate the homogeneity of the variances of the two groups. (Table4)

TABLE 4.

DESCRIPTIVE STATISTICS: LISTENING PRETEST

Group Statistics

\begin{tabular}{|l|l|l|l|l|l|}
\hline & GROUP & N & Mean & Std. Deviation & Std. Error Mean \\
\hline $\begin{array}{l}\text { Listening } \\
\text { pretest }\end{array}$ & experimental & 64 & 21.0625 & 3.62038 & .45255 \\
\hline
\end{tabular}

At the end of the term in order to investigate the effect of our treatment on the subjects listening comprehension skill another test of listening was administered to the students, the results of which were analyzed through an independent $\mathrm{t}-$ test to see whether the treatment improved the subjects' listening skill or not (Table5). 
TABLE5.

INDEPENDENT T-TEST: LISTENING POSTTEST

Independent Samples Test

\begin{tabular}{|c|c|c|c|c|c|c|c|c|c|c|}
\hline & & \multicolumn{2}{|c|}{$\begin{array}{l}\text { Levene's Test for } \\
\text { Equality of Variances }\end{array}$} & \multicolumn{7}{|c|}{ t-test for Equality of Means } \\
\hline & & \multirow[t]{2}{*}{$\mathrm{F}$} & \multirow[t]{2}{*}{ Sig. } & \multirow[t]{2}{*}{$\mathrm{T}$} & \multirow{2}{*}{ df } & \multirow{2}{*}{$\begin{array}{l}\text { Sig. }(2- \\
\text { tailed) }\end{array}$} & \multirow{2}{*}{$\begin{array}{l}\text { Mean } \\
\text { Difference }\end{array}$} & \multirow{2}{*}{$\begin{array}{l}\text { Std. Error } \\
\text { Difference }\end{array}$} & \multicolumn{2}{|c|}{$\begin{array}{l}95 \% \text { Confidence Interval of the } \\
\text { Difference }\end{array}$} \\
\hline & & & & & & & & & Lower & Upper \\
\hline \multirow{2}{*}{$\begin{array}{l}\text { Listening } \\
\text { Post-test }\end{array}$} & $\begin{array}{l}\text { Equal variances } \\
\text { assumed }\end{array}$ & 8.594 & .004 & 7.961 & 115 & .000 & 3.7647 & .47291 & 2.82800 & 4.70148 \\
\hline & $\begin{array}{l}\text { Equal variances } \\
\text { not assumed }\end{array}$ & & & 7.773 & 96.716 & .000 & 3.7647 & .48431 & 2.80349 & 4.72599 \\
\hline
\end{tabular}

The F- test was also run to investigate the homogeneity of the variances of the two groups.(Table6)

TABLE 6

DESCRIPTIVE STATISTICS: LisTENING POSTTEST Group Statistics

\begin{tabular}{|l|l|l|l|l|l|}
\hline & GROUP & $\mathrm{N}$ & Mean & Std. Deviation & Std. Error Mean \\
\hline $\begin{array}{l}\text { Listening } \\
\text { Posttest }\end{array}$ & Experimental & 64 & 25.4063 & 2.23052 & .27881 \\
\cline { 2 - 7 } & Control & 53 & 21.6415 & 2.88294 & .39600 \\
\hline
\end{tabular}

And finally Schimidt's test of motivation was administered again as the post test of motivation to see if the treatment had any effect on the motivation of the subjects.

The collected data were analyzed to determine whether:

Motivating the Iranian EFL learners via visuals has any impact on their listening comprehension.

The following tables display the descriptive statistics for the experimental, and control groups, together with the total number subjects statistics.

TABLE 7.

DESCRIPTIVE STATISTICS: TOTAL SUBJECTS

Descriptive Statistics

\begin{tabular}{|l|l|l|l|l|l|l|}
\hline & $\mathrm{N}$ & Minimum & Maximum & Mean & Std. Deviation & Variance \\
\hline MOTIVATION PRETEST & 88 & 100.00 & 181.00 & 159.1705 & 17.13384 & 293.568 \\
\hline MOTIVATION POSTTEST & 117 & 42.00 & 103.00 & 79.5385 & 11.67486 & 136.302 \\
\hline PROFICIENCY & 117 & 12.00 & 31.00 & 23.2564 & 4.18362 & 17.503 \\
\hline LISTENING PRETEST & 117 & 9.00 & 29.00 & 21.0940 & 3.51593 & 12.362 \\
\hline LISTENING POSTTEST & 117 & 16.00 & 30.00 & 23.7009 & 3.15754 & 9.970 \\
\hline MOTIVATION POSTTEST & 117 & 43.00 & 104.00 & 84.7436 & 11.65684 & 135.882 \\
\hline
\end{tabular}

TABLE 8.

DESCRIPTIVE STATISTICS: EXPERIMENTAL GROUP

Descriptive Statistics

\begin{tabular}{|l|l|l|l|l|l|l|}
\hline & N & Minimum & Maximum & Mean & Std. Deviation & Variance \\
\hline MOTIVATION PRETEST & 47 & 100.00 & 180.00 & 159.1702 & 16.77254 & 281.318 \\
\hline MOTIVATION POSTTEST & 64 & 42.00 & 103.00 & 77.6719 & 12.70427 & 161.399 \\
\hline PROFICIENCY & 64 & 13.00 & 31.00 & 23.6562 & 3.84303 & 14.769 \\
\hline LISTENING PRETEST & 64 & 13.00 & 28.00 & 21.0625 & 3.62038 & 13.107 \\
\hline LISTENING POSTTEST & 64 & 19.00 & 30.00 & 25.4062 & 2.23052 & 4.975 \\
\hline MOTIVATION POSTTEST & 64 & 62.00 & 104.00 & 89.5625 & 9.23911 & 85.361 \\
\hline
\end{tabular}


TABLE 9.

DESCRIPTIVE STATISTICS: CONTROL GROUP

Descriptive Statistics
\begin{tabular}{|l|l|c|c|c|c|c|c|}
\hline & N & Minimum & Maximum & Mean & Std. Deviation & Variance \\
\hline MOTIVATION PRETEST & 41 & 100.00 & 181.00 & 159.1707 & 17.74810 & 314.995 \\
\hline MOTIVATION POSTTEST & 53 & 61.00 & 100.00 & 81.7925 & 9.95250 & 99.052 \\
\hline PROFICIENCY & 53 & 12.00 & 31.00 & 22.7736 & 4.55159 & 20.717 \\
\hline LISTENING PRETEST & 53 & 9.00 & 29.00 & 21.1321 & 3.41961 & 11.694 \\
\hline LISTENING POSTTEST & 53 & 16.00 & 27.00 & 21.6415 & 2.88294 & 8.311 \\
\hline
\end{tabular}

\section{CONCLUSION}

The statistical procedures were conducted and applied to the gathered data the data from the first questionnaire were subjected to a t-test lending support to the claim that using visuals will improve the Iranian EFL learners' motivation; it will also improve Iranian EFL learners' listening comprehension. This small-scaled research demonstrates the value of pre-listening activities in elementary classes, which are most often neglected. The result of the study illustrates that elementary students can also benefit from a higher degree of motivation if they are made curious about what they are going to listen to and this happens when they have some information about what they are going to hear and they have an image of the situation in which the talking is taking place or the thing about which the topic of talking is related to. So pre listening activities are very helpful especially when as happened in this study are aimed at contextualizing the material for the students and they make them curious about what they are going to listen. Therefore, what I am suggesting is that a pre- listening activity which provides some extra information for the students from which they can benefit as some presupposition or provides an image of what they are listening to should become an inseparable part of all lecture- based classes, if the instructor wishes to promote better learning among his students. For example if the lecturer in a biology class is describing the biological system of one's body, his teaching would be more effective if he first tries to provide the students with an illustration of that system.

\section{REFERENCES}

[1] Anderson, A. \& Lynch, T. (1988).Listening. Oxford: Oxford University Press.

[2] Asher, J. (1977). Learning another language through action s: The complete Teacher's Guide book .Los Gatos, CA: Sky Oaks Productions.

[3] Atkinson, J.W. (1957).Motivational determinants of risk-taking behavior. Psychological review, 64, 359-372.

[4] Atkinson, J.W. (1964).An Introduction to Motivation. New York: D.Van Nostrand Company.

[5] Beck, R. C. (1990).Motivation: Theories and principles. Englewood cliffs: Prentice Hall.

[6] Brown, G. \& Yule, G. (1983). Discourse Analysis. Cambridge Textbooks in Linguistics.

[7] Brown,H.D. (1994).Principles of language learning and teaching. Third Edition. Sanfrancisco state University: Prentice Hall Regnts Englewood Cliffs.

[8] Brown, H.D. (2000). Teaching by Principles, an Interactive Approach to Language Pedagogy. Sanfrancisco State University.

[9] Cook,V. (1991).Second language learning and teaching .London: Edward Arnold.

[10] Galindo, I. (1997). Adding motivation in your teaching. Church teaching today .Retrieved January 2004, From http:www.Galindo co/flies/ctt jan97.pdf.

[11] Krashen, S. (1985). The Input Hypothesis .London: Longman.

[12] Morely, J. (1994). Listening Comprehension in Second/foreign Language Instruction. Marianne CeleMuriccia, Editor: University of California, Los Angeles, Heinle \& Heinle Publishers.

[13] Murray, H.A. (1938). Explanation in Personality. New York: Oxford University Press.

[14] Morreale,S. P. (2001). Human Communication: Motivation, Knowledge \&Skills. Belmont, Wardroth: Thomas Learning.

[15] Nunan, D. (1991). Language Teaching Methodology: A Text book for Teachers. New York: Prentice Hall.

[16] Petri, H.L. (1990). Motivation: Theory and Research. America: Wadsworth.

[17] Sheerin, S. (1987). Listening Comprehension: Teaching or testing? ELT Journal, 41(2), 126-131.

[18] Sherwyn,P. (2001). Human Communication: Motivation, Knowledge and Skills. Belmont wood north Thompson.

[19] Spaulding,C.L. (1992). Motivation in the Classroom. University of Connecticut, MC. Grav Hill/Inc.

[20] Thorndike, E.L. (1932). The fundamentals of Learning. New York: Colombia University Press.

[21] Ur, P. (1984). Teaching Listening Comprehension. Cambridge: Cambridge University.

[22] Vygotsky,L.S. (1987).Mind in Society: The Development of Higher Psychological Process. Massachusetts: Harvard University Press. 


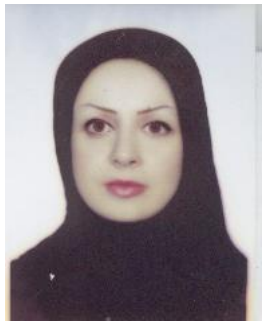

Masoumeh Karimi is a Ph.D student of Azad University. She has taught English in different Language institutes including Iran Language Institute in Iran. She has also taught different subjects in different universities and has translated some books.

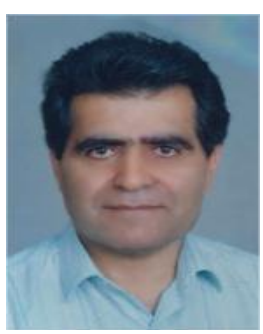

Reza Biria, born in Isfahan, Iran, obtained his Ph.D. in teaching English as a Foreign Language from the University of Isfahan in 2001. He is an applied linguistics assistant professor working at Khorasgan Azad University, Isfahan, Iran. Dr. Biria has published papers in national and international conferences. His research interests include teaching English as a second and foreign language and ESP. 